\title{
GEOPHYSICAL SURVEYS
}

\section{at the West End Cemetery, Townsville: An Application of Three Techniques}

\section{Ross Stanger ${ }^{1}$ and David Roe ${ }^{2}$}

\section{Abstract}

Geophysical surveys were undertaken at Townsville's West End Cemetery to examine the cultural and/or ethnic association of graves and to test the potential use of different forms of geophysical prospection on archaeological sites in north Queensland environments. Surveys focused on an area of the cemetery known as 'E Block', which contained little physical or historical evidence for burials but was believed to have been used for the interment of 'nonChristian' individuals. While results from the resistivity and ground penetrating radar surveys were inconclusive, the magnetometry surveys located the graves of 65 individuals. Details on each individual's cultural attributes derived from the cemetery's burial register indicated that they were from a diverse range of ethnic and cultural backgrounds, many of which were previously unrepresented amongst extant grave markers. Results provided information that could not be gained from any other source, and enabled the critical examination of aspects of the cemetery including the past management regime, the spatial patterning of graves and whether or not an individual's ethnic, social or economic characteristics contributed to their spatial placement.

\section{Introduction}

This paper presents the results of geophysical surveys undertaken at the West End Cemetery in Townsville, Queensland. The surveys were performed with the dual purposes of generating spatial data to assist the cxamination of the cultural and/or ethnic associations of graves within the cemetery grounds, as well as to test the potential of several forms of remote sensing techniques within that environment. The surveys focused on E Block, an area with few extant memorials or physical indicators and limited historical information, but widely believed, by the local community, to be the 'non-Christian' sector of the original cemetery.

Historical Background

The West End Cemetery was established in 1866, shortly after the establishment of Townsville. Initially surveyed beyond the town boundary, the grounds are located at the base of Castle Hill and are bounded by Francis Street to the north and Church Street to the west (Figure 1). The grounds appear to have been in use from as early as 1868 with records indicating that a cemetery committee had been formed and public donations collected for the fencing of the area (Cleveland Bay Express 26 September, 1868). There are no known burial records for the first four years.

In 1872 Trustees were appointed to manage the cemetery (Queensland Government Gazette 31 August 1872:1372) with

Cambridge Archaeological Unit, University of Cambridge, 34a Storeys Way, Cambridge CU3 ODT, United Kingdom

2 Department of Anthropology, Archaeology and Sociology, James Cook University, Townsville, OLD 4810, Australia

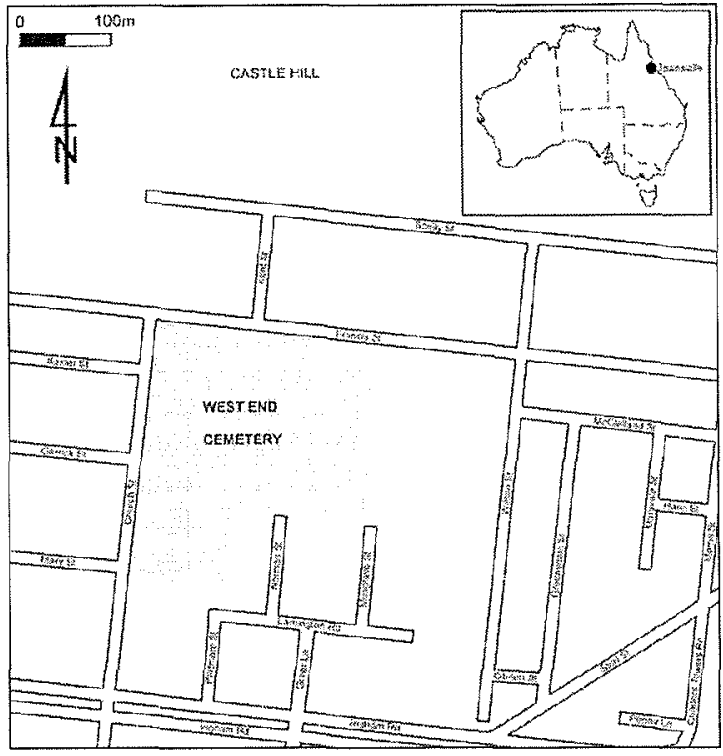

Figure 1 Suburb of West End, Townsvifle, showing location of West End Cemetery (after Anon. 2001:Map 35).

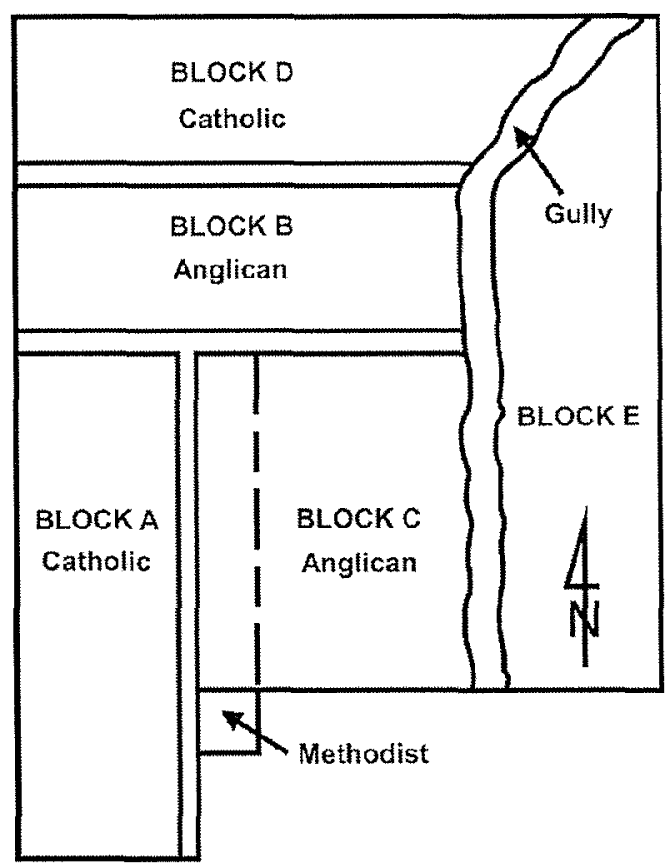

Figure 2 Redrawn sketch plan of the possible past layout of the West End Cemetery. Sketch may have been based on an old survey plan (after Bell and Young 1997:4). 


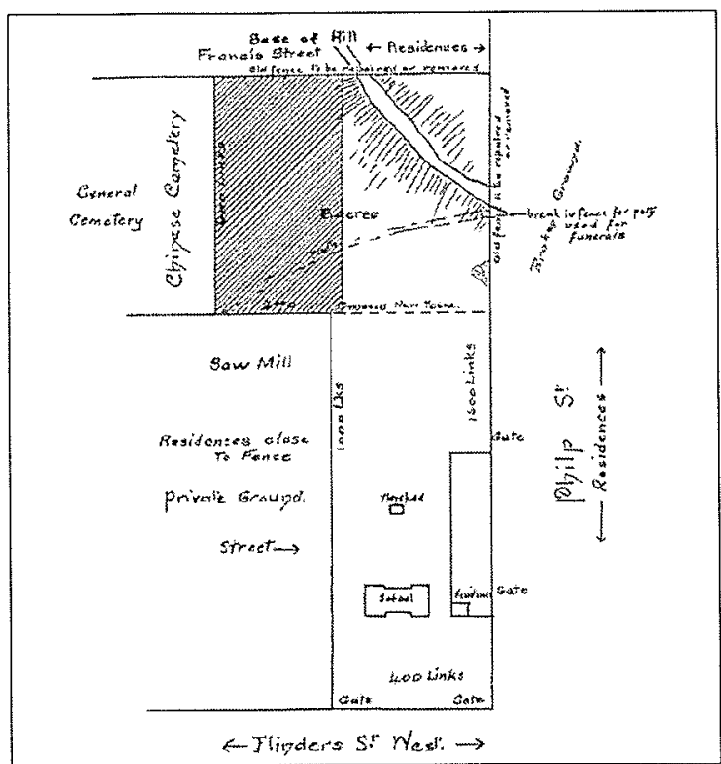

Figure 31900 sketch map of Townsville West State School and 'Chinese Cemetery' (E Block) (Stuart 1987:7).

records being maintained from late 1873 onwards. The site was managed according to the Queensland Cemetery Act 1865, with a set of local cemetery rules based on this act being published in the Queensland Government Gazette (26 July 1873:1235-1236) Among their responsibilities, the Trustees were to create and maintain a plan of the position of all graves, which was to be available for public inspection.

A sketch plan of the West End Cemetery held by the sexton provides perhaps the only historical link for the formal designation of denominational areas in the cemetery (Figure 2). This plan was redrawn by Bell and Young (1997), who suggest that the sketch may have been based on an old survey plan of the grounds (P. Bell, pers. comm., 2 October 2007). The plan shows that the land to the west of the gully that runs approximately north-south through the cemetery was used for the burial of Christian individuals and was divided into Anglican, Catholic and Methodist areas (A-D Blocks). The land to the east of the gully ( $\mathrm{E}$ Block) is not labelled as an area for any particular denomination and may have been intended for the burial of individuals who were non-Christian.

A sketch map drawn in 1900 of the neighbouring Townsville West State School provides further information on the individuals buried in E Block (Figure 3) (Stuart 1987:7). The map labels the area as the 'Chinese Cemetery' with a pathway providing access to the area from the school grounds. A significant Chinese population lived in Townsville from its establishment (Harvey 2001); more than 200 individuals have been identified as Chinese in the post- 1873 West End Cemetery Burial Register.

In 1902 a new cemetery reserve was established in the suburb of German Gardens (later renamed Belgian Gardens), both as a result of the declining space in the West End Cemetery and owing to concerns regarding the possible contamination of the creek which ran through the site. Although officially closed in 1925 (Queensland Government Gazette 4 April 1925:1642), burials continue to be undertaken at the cemetery in familyowned plots.

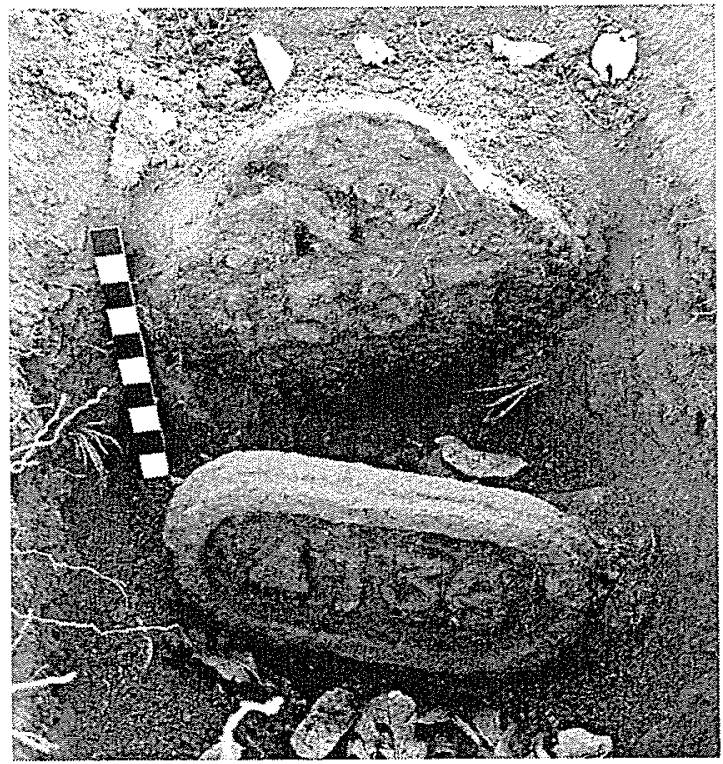

Figure 4 Two in situ grave markers (1597/4136), West End Cemetery. Scale $=1 \mathrm{~cm}$ intervals (Photograph: David Roe).

Between its closure and the 1990 s the cemetery fell into general disrepair. This was largely due to the high cost of maintaining two cemeteries, with a large share of funds used at the 'working' Belgian Gardens Cemetery. From at least the 1950s the Trustees requested financial assistance from the Townsville City Council for the upkeep of the West End Cemetery (Townsville Cemetery Trust 18 November 1955; see also 16 May 1958, 29 January 1964). In 1969 the Townsville City Council approved $\$ 1500$ of annual financial assistance for the upkeep and maintenance of the cemetery (Townsville Cemetery Trust 23 April 1969).

In 1955 the Trustees asked for permission from the Queensland Lands Department to sell all the land in E Block (Townsville Cernetery Trust 8 November 1955) to ease the financial burden. In this correspondence the Trustees indicated that 36 burials with 16 monuments were present in E Block. The proposal was declined, with the Lands Department claiming that at least 40 burials were in the area (Land Administration Board 9 February 1956). A second attempt by the Trustees to divest themselves of $\mathrm{E}$ Block was made in 1965 when they asked the Townsville City Council to take over the area with a view to subdividing it into residential blocks ('lownsville Cemetery Trust 25 May 1965, 30 March 1967). The correspondence indicated that just 26 burials were present in the area. The proposal was rejected due to the high costs associated with exhumation, reinterment and redevelopment (Bell and Young 1997:8) and effectively ended further attempts to relinquish land from the cemetery grounds. These sources provide information on the potential numbers of graves in $\mathrm{E}$ Block; however, the discrepancies in the burial numbers justified further research in the area.

In 1994 the site was listed on the Queensland Heritage Register (Lucas 1994). In 1996 the Townsville City Council commissioned the formulation of a Conservation Strategy to provide direction and guidelines for the care and maintenance of the cemetery grounds (Bell and Young 1997).

The research and fieldwork relating to this paper were undertaken between February and October 2004. 


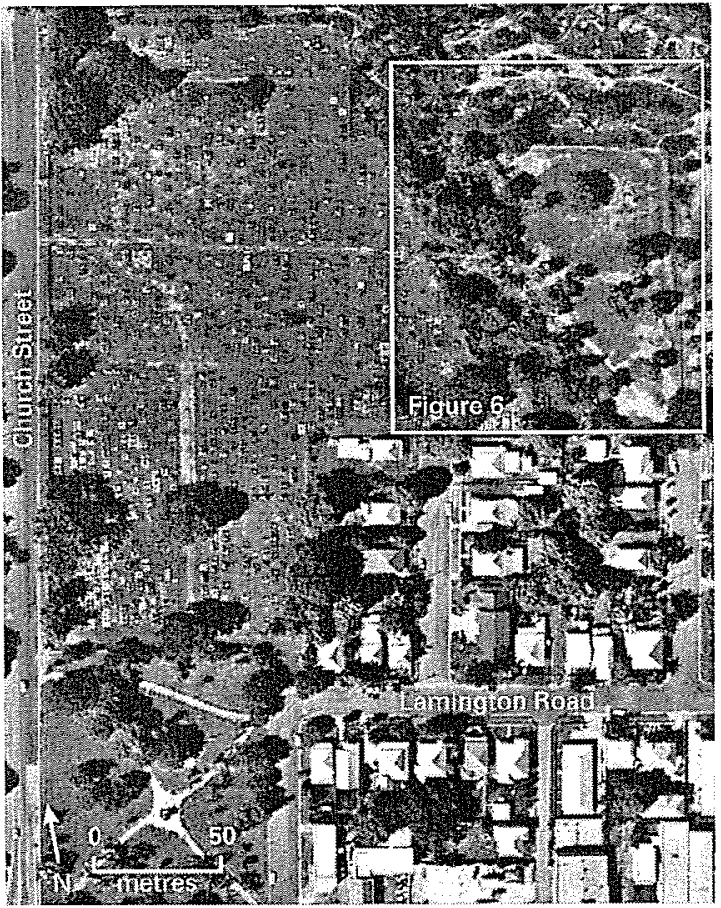

Figure 5 Aerial photograph of West End Cemetery, 2001 lafter Townsville City Council, Land Information Unit).

\section{Site Background}

The official record of burials in the cemetery is the West End Cemetery Burial Register, which documents burials conducted between 1873 and 1989. Information in the Register includes the deceased's name, place of birth, date of death, religious affiliation, and burial number. A cast-iron marker (grave marker) with the individual's burial number was placed in the ground at either the foot or head of each grave (Figure 4). Individuals could be located by using the number recorded in the Register and then referring to the cemetery plan which showed the positions of the markers and burials. Unfortunately this plan has been lost.

The Register records the interment of approximately 7900 individuals at the cemetery. There are 2210 individuals each marked by a monumental grave, accounting for approximately $28 \%$ of the total number of burials. The remaining 5690 burials ( $72 \%$ of the total) are either physically marked with an in situ numbered grave marker, but no monument (numbered grave), or are not now marked by either a monument or grave marker (unmarked grave).

As noted above, the cemetery grounds are divided into a western section (Blocks A-D) and an eastern section (Block E) by a deep natural gully running from the north to the south (Figure 5). Blocks A-D contain monuments which were erected for individuals of various Christian denominations, as well as areas with no monuments, which include numbered and unmarked graves. Although the historical record indicates there were separate areas for the different denominations, there is no immediate physical evidence of distinct clusters for other cultural and/or ethnic associations within these. The distribution of numbered and unmarked graves between monumental graves suggests that the socio-economic status of individuals does not

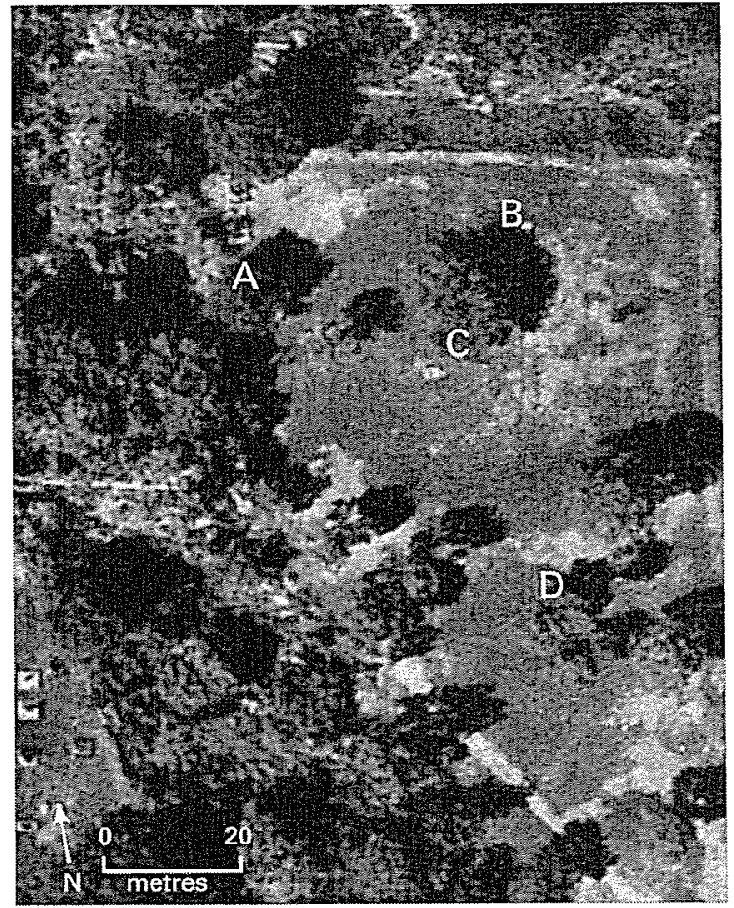

Figure 6 Aorial photograph of E Block, West End Cemetery, 2001. Letters indicate locations of monument groupings listed in text (after Townsville City Council, Land Information Unit).

appear to have been a factor contributing to the spatial patterning of burials in Blocks A-D at the cemetery.

E Block is different in terms of its monument distribution pattern as it contains very few extant monuments and those present are clustered into distinct groups (Figure 6). These include a line of 14 monuments along the western edge of the area and along the eastern rim of the gully $(\mathrm{A})$; a monument foundation (unknown individual) (B); two monuments erected for a Japanese sailor (C); and two monuments marking the graves of three individuals and one monument for four individuals (D). The 20 monuments that stand in E Block record the deaths of 33 individuals; 14 monuments being for individuals of Christian affliation, three for individuals of Jewish-Hebrew faith, one for an individual/s whose affiliation/s we cannot determine (monument foundation), while the remaining two monuments were for the Japanese sailor (C) listed as having an unknown affiliation. Importantly, of these monuments, the three erected for those of Jewish-Hcbrew affiliation and possibly the monument foundation are the only physical evidence for the possible past use of the area for the burial of individuals who were not Christian. The burials in $\mathrm{E}$ Block were undertaken between 1887 and 1946.

Three graves without monuments but with grave markers visible on the surface were also identified. Importantly, the number of burials physically marked in the area is less than the 36 listed by the Trustees in 1955 during their attempt to sell the land. This suggests that at least three burials may have been 'lost' between 1955 and the present day. No further physical evidence is present to indicate different cultural and/or ethnic groups in E Block even though the Register indicates a wide range of culturally distinct groups are represented by the interments in 


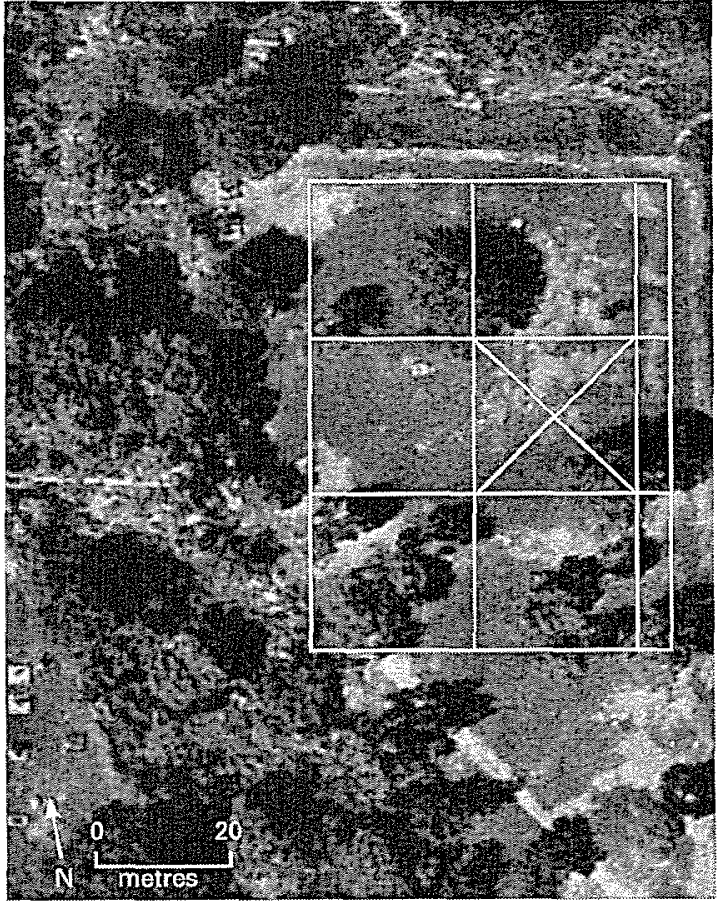

Figure 7 Aerial photograph of E Block, West End Cemetery, indicating locations of squares surveyed during fieldwork. The square marked with a cross was the area initially surveyed (Square E) (after Townsville City Council, Land Information Unit).

the grounds. There are a number of possible explanations for this, including that no monuments were erected, that monuments disappeared due to natural processes such as weathering, fire or termites, or that monuments were deliberately removed either by management, family or vandals.

Among those not represented by monuments within the cemetery are cultural groups such as Chinese and South Sea Islanders. These groups played an important role in the development of Townsville providing, amongst other things labour for nearby mining and agricultural operations and stores to service the fledgling settlement. They were, however, an impermanent part of the community as, particularly towards the end of the 1800 s, the dwindling output of mining operations and restrictive government policies caused emigration, relocation to other areas and finally a virtual end to the immigration of these diverse cultural groups. This may provide further reasons for their lack of monumental representation within the grounds despite their identification in the Register.

There are several other noticeable differences between Blocks A-D and Block E. Major differences include the pathways and vegetation in each section. Distinct, linear pathways are present in Blocks $A$-D that roughly coincide with earlier cemetery paths. Conversely, the $\mathrm{E}$ Block area contains just one vehicle track (Figures 5-6). Other noticeable differences between the Blocks $\mathrm{A}-\mathrm{D}$ and $\mathrm{E}$ can be seen in the different vegetation patterns and the maintenance regimes for this vegetation. Blocks $A-D$ have a number of native grass species and trees such as banyans, mahoganies, frangipanis and palms, which appear to have been planted in rows often along well-defined pathways. The grass and vegetation is well-maintained through mowing and trimming
(Figure 5). E Block contains a number of native and introduced grasses and weeds, as well as mahoganies and eucalypts, which are dispersed throughout the area. The grass is rarely mown and eucalypt saplings are present across the ground surface (Figures 5-6).

\section{Geophysical Surveys}

Critical review of previous archaeological studies and modern records of the cemetery's burials and monuments, as well as reanalysis of primary historical material, provided an understanding of the cultural and/or ethnic associations in Blocks $\Lambda-D$, but did not provide adequate information for $E$ Block. The discovery of grave markers in E Block indicated that numbered graves and possibly unmarked graves were present. Geophysical surveys were suggested as a potential technique for data acquisition. However, there has been limited archaeological remote sensing in north Queensland, so ground penetrating radar (GPR), a resistance meter and a magnetometer were all used over the survey area to determine which instrument might be best suited to the conditions and circumstances of the West End Cemetery.

\section{Topographical Information}

The ground surface of $\mathrm{E}$ Block slopes gently downward from north to south. A number of large mahogany and eucalypts are present with their roots having the potential to affect the instrument readings, in particular, the GPR signals.

The dominant soil type of the West End Cemetery is red earth (Murtha and Reid 1992). The major characteristics of the soil consist of grey-brown loamy sand to sandy loam in Horizon A, with Horizon $B$ consisting of red or yellowish sandy clay loam. The soil drains quickly and is loosely packed.

\section{Survey Methodology}

The initial survey phase in E Block involved the use of each instrument on an initial $20 \mathrm{~m} \times 20 \mathrm{~m}$ square (Square E, $400 \mathrm{~m}^{2}$ ), oriented north-south ( $\mathrm{x}$-axis) by east-west ( $\mathrm{y}$-axis) (Figures 7 and 11 ). Using the gradiometer alone the survey was expanded to cover a further five $20 \mathrm{~m} \times 20 \mathrm{~m}$ squares $(A, B, D, G$, and $H)$ and three $20 \mathrm{~m} \times 5 \mathrm{~m}$ squares (C, F and I), using the same grid. The survey squares were established between existing monuments and landscape features, necessitating the inclusion of some 'dummy data' where these elements obstructed the survey transects. Particular attention was paid to the area where the several nonmonumental numbered graves were identified.

\section{Technique and Instruments}

Ground penetrating radars (GPR) are shallow seismic devices, which use microfrequency (VHF) radar pulses/waves to detect subsurface features (Garrison and Herz 1998:170). Information is attained by these waves reflecting off subsurface features (Conyers and Goodman 1997:13) and measuring the time taken for their return. Archaeological features will cause the waves to be reflected at a different rate from the material surrounding them, with this difference being recorded by the instrument.

The GPR used was a RAMAC (Mala) instrument. Both $250 \mathrm{MHz}$ and $500 \mathrm{MHz}$ antennas were tested to determine which was the most useful for the conditions. Traverses were undertaken every $50 \mathrm{~cm}$ with readings taken continuously by 


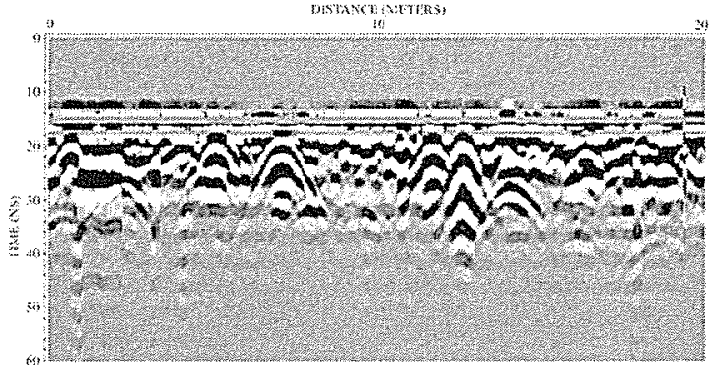

Figure 8 GPR results for initial survey square, E Block.

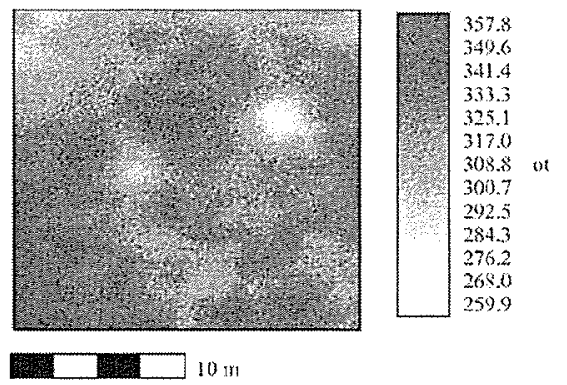

Figure 9 Resistance meter results for initial survey square, E Block.

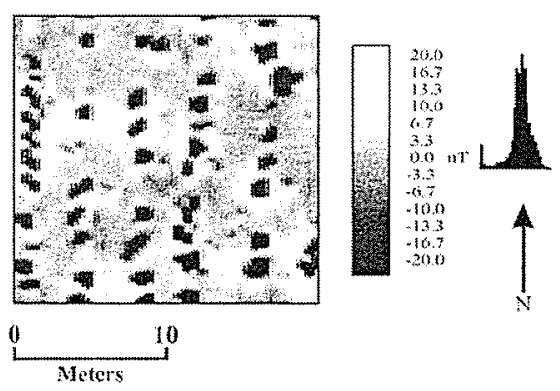

Figure 10 Magnetometer results for initial survey square, E Block.

the movement of the GPR cart. Data were processed using Mala REFLEX software.

$\triangle$ resistivity meter is a geophysical instrument that measures the electrical resistivity of the soil. Resistivity is a mensure of the ease with which an electrical current travels through the soil between the two probes of the meter. The archaeological application of resistivity measurements involves inferring the presence of artefacts and features from differences in electric resistivity produced by different soils or by foreign objects (Nishimura 2001:544). The electrical resistance of soil depends on several factors including soil structure, dissolved ion content, and moisture content (Weymouth 1986:318); for these reasons some archaeological features such as pits, ditches and walls will affect soil resistivity.

The resistivity meter used was the RM15, produced by Geoscan. The survey involved traverses every $50 \mathrm{~cm}$ with $50 \mathrm{~cm}$ sampling intervals along each traverse. The probe spacing used on the instrument was $50 \mathrm{~cm}$ with the internal/automaticlogging of data undertaken. Data were processed and analysed using GEOPLOT 3.0 software.

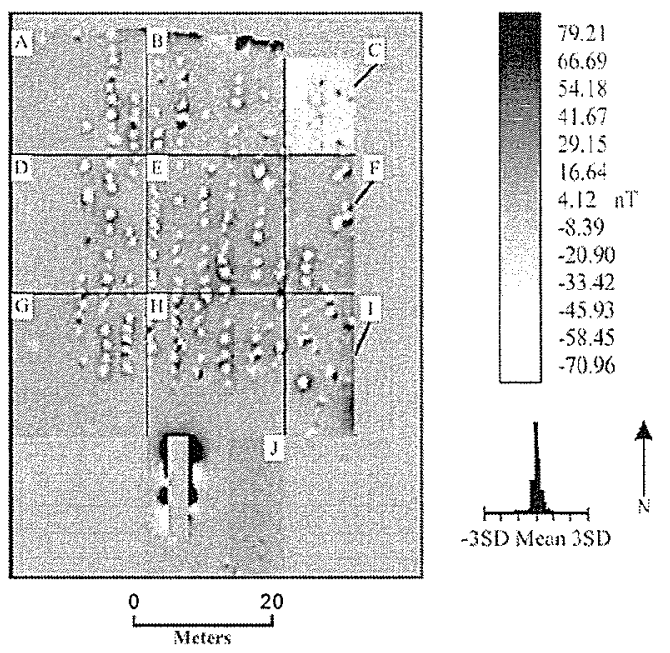

Figure 11 Expanded survey results for magnetometer. Square $E$ is the square initially surveyed. $20 \mathrm{~m} \times 5 \mathrm{~m}$ surveys were undertaken in Squares $C, F$ and I due to the slope towards the school ground and the Squares $C, F$ and $I$ due to the slope towards the school ground and the
metal boundary fence. White circular features represent high intensity signals. Rectangular features to the west in Square $D$ and the south in Square $J$ are monumental graves where dummy readings were given to avoid metallic interference.

A magnetometer measures the magnetic contrast between an object or feature and its burial context (Garrison and Herz 1998:167). Within archaeology the use of magnetometers is based on the principle that if there is a difference between an archaeological feature and the surrounding soil, there will be a difference in their effect on the earth's magnetic field (Leute 1987:14).

The magnetometer used during the surveys at West End Cemetery was a Fluxgate Gradiometer (FM256), produced by Geoscan. Survey was undertaken on Square $\mathrm{E}$ with a traverse interval of $50 \mathrm{~cm}$ and a sampling interval of $25 \mathrm{~cm}$ on each traverse. Data were logged using an automatic internal trigger and processed and analysed using GEOPLOT 3.0 software.

\section{Results: Geophysical Surveys and Excavation}

Results from the initial geophysical surveys conducted in $\mathrm{E}$ Block are shown in Figures 8, 9 and 10; results from the expanded magnetometry survey are shown in Figure 11.

A single GPR trace/slice generated during the initial geophysical survey using a RAMAC with the $250 \mathrm{MHz}$ antenna is shown in Figure 8. This indicates that a large number of anomalies are present, although initially it was difficult to interpret these results and be certain that the areas indicated were features related to numbered or unmarked graves. Although the RM15 resistance meter survey did not locate individual graves (Figure 9), areas of lower resistivity were identified and could be associated with disturbed soil brought about by the digging of a grave. However, these areas appear to be randomly dispersed throughout, making it difficult to establish whether the results indicated the presence of graves.

The fluxgate gradiometer magnetometry survey provided the most impressive results from the initial survey square (Figure 10). The regular spacing of high-intensity signals (visible as black circular shapes), as well as the coincidence of some of these 


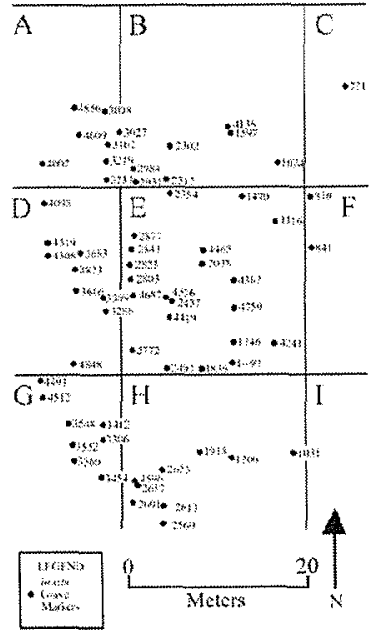

Figure 12 Location of in situ grave markers/numbered graves in $E$ Block. Numbers together with two grave marker symbols represent two markers located with one another in situ suggesting reuse of burial plots.

signals with the visible cast-iron grave markers, suggested that these were also buried grave markers. Positions also matched the subsurface anomalies indicated by the GPR survey. Given these initial results the gradiometer surveys were then extended to the other eight squares described above, effectively covering the entire E Block area (Figure 11).

Following the completion of the survey, discrete excavations were undertaken of the anomalies revealed by geophysical survey. This involved excavation by trowel of areas approximately $25 \mathrm{~cm}$ $x 25 \mathrm{~cm}$ to a depth where the nature of the anomaly could be ascertained. Care was exercised not to disturb the graves themselves. These targeted excavations revealed the presence of 65 'complete' and in situ numbered grave markers, at depths of up to $35 \mathrm{~cm}$ (Figure 12), and occasionally as pairs (Figure 4). The remaining anomalies were identified as displaced complete markers, in situ or displaced cast iron spikes (markers lacking the numbered plate), or broken or fragmented marker parts.

Cross-referencing the marker numbers to the Register provided the names and details of those buried and usually their cultural and/or ethnic association. From the identificd burials, 42 individuals were recorded as having been born in China, while 19 individuals were variously recorded as having come from the South Sea Islands, Germany, Ireland, England, Townsville, India and Indonesia. The birthplaces of four individuals were not recorded in the Register. The people buried in E Block include Christians and non-Christians and those whose religious affiliation was not known. More specifically the burials belong to Anglicans, Roman Catholics, Wesleyans, 'Heathens' and 'Pagans'. Dates for the burials associated with these markers ranged from 1883 to 1903.

The survey and excavation data can be used to establish a chronology of the 'take up' of E Block grave plots, their placement with respect to other burials and their schedule of reuse, as well as providing a better understanding of the management regime at the site. More importantly, the new data allowed for the consideration of whether birth place and/or cultural and religious affiliations were significant factors in the patterning of grave placements at the West End Cemetery in general and within $\mathrm{E}$ Block in particular.

\section{Conclusion}

The data generated by the geophysical surveys at the West End Cemetery provided information that could not be obtained from any other source. The success of the magnetometry surveys in relocating burial markers was not mir rored by the results of either GPR or resistivity techniques in relocating graves. However, the equivocal results from the latter two approaches require further consideration. Local environmental factors, including soil types and rainfall regimes, may well be significant factors here but further geophysical surveys in north Queensland are required to establish datasets for comparative analysis. The widespread use of numbered metal grave markers in north Queensland cemeteries suggests that the relocation of burials in such sites may not have to rely on the presence of identifiable grave cuts that might be indicated by GPR and/or resistivity surveys nor the presence of grave artefacts (coffin fittings etc) detectable by magnetometry. The presence of so many buried markers in E Block was unexpected and may be the result of deliberate landscape alteration and/or the 'driving-in' of markers so as not to interfere with grass-mowing regimes.

The geophysical surveys have considerably expanded the known distribution of burials at the cemetery. Furthermore, they have also enabled the critical examination of past cemetery management regimes, a greater understanding of the overall patterning of graves within the grounds and the construction of a chronology of changes to $E$ Block over time, providing a more complete history of the cemetery.

As a significant proportion of the individuals buried in $\mathrm{E}$ Block could be identified; questions regarding the ethnic, social or economic factors that may have determined burial in this discrete area could be addressed. Although further analysis and interpretation of the results is continuing, some initial obscrvations may be made about the 'rules' of burial in $\mathrm{E}$ Block. Clearly the marking of graves in this area followed the standard pattern used elsewhere in the cemetery. However, locating a burial here seems to have been governed by a number of factors. The presence of some Christians, for example, suggests that religious affiliation by itself may not have been sufficient reason for burial in Blocks A-D. Similarly, the burial of Europeans suggests that ethnicity was not the sole determining factor in decisions relating to an appropriate location for a final resting place. Other factors, possibly including personal choice and the manner of death, are clearly also at play. E Block certainly represents a burial area for individuals and groups whose interment in the Christian and Jewish areas of the cemetery could not be entertained but who, nevertheless, deserved a proper place of burial in accordance with the regulations.

In 2005 the Townsville City Council marked the 65 graves with individual brass plaques mounted onto concrete plinths and thus, possibly for the first time, those buried here were accorded the dignity of having their graves marked with their name and place of origin. The geophysical surveys at the West End Cemetery have, therefore, not only provided new archaeological datasets but effectively recognised and reincorporated important but 'lost' cultural/ethnic communities that played an important role in the development of Townsville. 


\section{Acknowledgements}

We would like to thank the staff and students of the School of Anthropology, Archaeology and Sociology at James Cook University who assisted in various stages of this project both in the field and at the desk. Thank you also to Tracey Love from the Infohelp Department of the James Cook University Library and Shiranthi Siyambalapitiya from the Queensland State Archives. John Weir's incomparable knowledge of the cemetery and its history was invaluable. Jo Prego and Tanya Willis of the Special Projects Unit and the staff in the Land Information Unit of the Townsville City Council allowed access to council records and provided significant support for the project. Martin Gibbs and Ricky Patten provided valuable comments on drafts of this paper and Jackie Hutton from the Cambridge Archaeological Unit assisted with the preparation of figures and plates.

\section{References}

Anon. 2001 UBD Townsville and Thuringowa Street Directory, 6th Edition. Brisbane: Lniversal Press.

Bell, P. and D. Young 1997 West End Cemetery Townsville: Conservation Strategy. Unpublished report to Townsville City Council, Townsville.

Conyers, L.B. and D. Goodman 1997 Ground Penetrating Radar: An Introduction for Archaeologists. Walnut Creek, CA: AltaMira Press.

Garrison, E.G. and N. Herz 1998 Geological Methods for Archaeology. New York; Oxford University Press.
Harvey, T. 2001 Missing Persons: The Chinese in Townsville, 1864-1940. Unpublished BA (Hons) thesis, Department of Anthropology, Archaeology and Sociology, James Cook University, Townsville.

Land Administration Board 1956 Letter to Townsville Cemetery Trust, 9 February 1956. Held by Environmental Protection Agency, Townsville.

Leute, U.1987 Archaeometry: An Introduction to Physical Methods in Archaeology and the History of Art. Weinheim: VCH Publishers.

Lucas, H. 1994 Application for Entry into Queensland Heritage Register - West End Cemetery, Townsville. Unpublished application to Environmental Protection Agency, Queenstand.

Murtha, G.G. and R. Reid 1992 Soils of the Townsville Area in Relation to Urban Development. Division of Soils Divisional Report 11. Canberra: CSIRO.

Nishimura, Y. 2001 Geophysical prospection in archaeology. In D.R. Brothwell and A.M. Pollard (eds), Handbook of Archaeological Sciences, pp.543-553. London: John Wiley and Sons.

Stuart, A. (ed.) 1987 The Townsville West State School Centenary 1887-1987. Townsville: Townsville West State School.

Townsville Cemetery Trust 1955-1969 Minutes. Held by Environmental Protection Agency, Townsville.

West End Cemetery Burial Register 1873-1989. Held by Family History Association of North Queensland, Townsville.

Weymouth, J.W. 1986 Geophysical methods of archaeological site surveying. Advances in Archaeoological Method and Theory 9:311-395. 